\title{
Heritability and repeatability of the number of lambs born and reared estimated using linear and threshold models
}

\author{
Dariusz Piwczyński, Bogna Kowaliszyn and Sławomir Mroczkowski \\ Department of Genetics and General Animal Breeding, Faculty of Biology and Animal Breeding, University of \\ Agriculture and Life Sciences in Bydgoszcz, Poland
}

\begin{abstract}
The research was conducted on 3844 Polish Merino lamb dams born in 1991-2001, used in 15 flocks from the Pomerania and Kujawy region in Poland. The assessed parameters were the number of lambs born from a dam after lambing (LSB) $(1,2,3)$ and the number of lambs reared $(\operatorname{LSW})(0,1,2,3)$. The genetic parameters LSB and LSW were estimated with the use of two methods: Average Information - REML (AI-REML) and Gibbs sampling (GS). For estimation of components by means of the Al-REML method the animal's linear model was used, and in the case of the GS method a threshold model was also used alongside the linear one. The LSB heritability estimated using the Al-REML and GS methods in combination with a linear model were similar and their values were respectively 0.025 and 0.029 , with similar standard errors for variance components. Applying the GS method combined with a threshold model resulted in a two times higher heritability $(0.054)$ compared to when linear models were used. A similar tendency was found to exist in respect of estimated repeatability. When using linear models, the obtained values were closely matched: 0.064 (AI-REML) and 0.065 (GS). The highest repeatability occurred when a threshold model was used (0.118). The LSW heritability was low and, depending on the model and method $(0.016-0.020)$. Similar values LSW repeatability were obtained with the use of linear models (0.048 - REML and 0.049-GS), and when a threshold model was used the result was higher -0.070 .
\end{abstract}

Keywords: sheep, linear model, threshold model, genetic parameters, litter size, Merino

\section{Zusammenfassung}

\section{Bewertung der Heritabilität und Wiederholbarkeit der Anzahl von geborenen und aufgezogenen Lämmern mittels Linearen Modells und Schwellenmodells}

Die Untersuchungen wurden an 3844 Mutterschafen der Rasse Polnische Merino durchgeführt. Die Tiere stammten aus 15 Herden und wurden zwischen 1991 und 2001 in der Region Pommern und Kujawien in Polen geboren. Bewertet wurden die Anzahl der durch das Mutterschaf (LSB) geworfenen Lämmer $(1,2,3)$ und die Anzahl der aufgezogenen Lämmer (LSW) $(0,1,2,3)$. Die genetischen Parameter von LSB und LSW wurden mit Hilfe von zwei Verfahren bewertet: Average Information-REML (AI-REML) sowie Gibbs-Sampling-Verfahren (GS). Bei der Komponentenbewertung mit Al-REML wurde das lineare Modell des Tieres angewendet, bei GS zusätzlich das Schwellenmodell. Die Werte der Heritabilitätskennziffern von LSB, die unter Einsatz des Verfahrens AI-REML und GS in Verbindung mit dem 
linearen Modell bewertet wurden, waren angenähert und betrugen: 0,025 und 0,029 - bei vergleichbaren Fehlerwerten in Bezug auf die standardmäßige Varianzkomponente. Die Anwendung des GS-Verfahrens mit dem Schwellenmodell ergab einen doppelt höheren Wert der Heritabilität $(0,054)$ als beim linearen Modell.

Eine ähnliche Tendenz wurde im Bereich der Wiederholbarkeitskennziffern festgestellt. Angenäherte Werte wurden beim Einsatz des linearen Modells erreicht: 0,064 (Al-REML) und 0,065 (GS). Eine deutlich höhere Wiederholbarkeitskennziffer ergab sich bei der Anwendung des Schwellenmodells: 0,118. Die Heritabilität der Anzahl aufgezogener Lämmer war niedrig und schwankte abhängig von dem eingesetzten Modell und der angewendeten Methode zwischen 0,016 und 0,020.

Vergleichbare Werte der LSW-Wiederholbarkeit wurden bei Nutzung vom linearen Modell $(0,048$ - REML und 0,049 - GS) erreicht, ein deutlich höheres Ergebnis $(0,07)$ wurde dagegen bei Verwendung des Schwellenmodells errreicht.

Schlüsselwörter: Schaf, Lineares Modell, Schwellenmodell, genetische Parameter, Wurfgröße, Merino

\section{Introduction}

The Polish Merino is the most commonly used sheep breed in Poland. It comes from the French Merino Precoz which was improved after World War II with the breeds of the German, Caucasian Merino. The breeding of the Polish Merino is centred in the regions of Wielkopolska, and Pomerania and Kujawy. Ewes of this breed in 2008 constituted approximately $14 \%$ of female sheep being assessed in terms of their performance in Poland (Sheep and Goats Breeding in Poland in 2008, 2009).

Merino Sheep are much more common in countries to the west of Poland, for instance, in Germany. Based on the research conducted by Süß et al. (2004) it was established that the proportion of German Mutton Merino and Merinoland Sheep in the Saxon-Anhalt region is as high as $57.7 \%$. The used merinos are most frequently of the wool-meat type. The mean prolificacy of the breed in 2008 was relatively low and equalled $128.3 \%$. It is a clearly lower level than that presented by Strittmatter (2004) with respect to HB-German Mutton Merino $-146-168.8 \%$.

Variables like number of lambs born and reared take discrete values. These traits are considered threshold variables, that is traits which are discontinuous in their expression, usually representing a number of categorized phenotypic values, however, they are conditioned by polygenes (Dempster \& Lerner 1950, Gianola 1982). Their characteristic property is the fact that exceeding the so-called threshold referring to the genes possessed results in a fundamental change of the phenotype.

The distribution of these variables is incompatible with a normal distribution. Therefore prior to estimation of the (co)variance components the said traits must undergo the Snell transformation (Naazie et al. 1991), or a probit transformation (Piwczyński 2004), then linear model calculations may be made using the REML method. Matos et al. (1997a), De Vries et al. (2005) and Olesen et al. (1994), estimating genetic parameters, applied, as one of the models which it is possible to use for estimation of prolificacy variance components, the Poisson 
model. Results of numerous research studies (Altarriba et al. 1998, Matos et al. 1997a, 1997b, Olesen et al. 1994, Yazdi et al. 1999) show on the other hand that the genetic parameters of discreet reproduction traits should be estimated with the use of threshold models. Genetic parameters of reproduction traits may be estimated with the use of multitrait models (Hagger 2002, Vries et al. 1998) as well as repeatability models; results for these models are usually published in subject-related scientific literature (Dobek et al. 2004, Matos et al. 1997a, Noor et al. 2001, Olesen et al. 1994, Saboulard et al. 1995, Schmalwasser et al. 1991, Piwczyński 2009). It must be emphasised though that multitrait models have advantage over repeatability models as they take into account covariance between values of a trait obtained in subsequent measurements (Szyda 2001). Apart from establishing correct model selection, the researcher must choose between estimation methods. Usually, genetic parameters of the aforementioned reproduction traits are determined with the use of the Restricted Maximum Likelihood (REMLS), and Gibbs sampling.

Estimations of genetic parameters conducted so far indicate low influence of genetic assumptions on reproduction traits in Merino sheep ( $h^{2}$ : fertility - 0.0720-0.203; number of lambs born from a mother that had lambed before $-0.060-0.260$; number of lambs reared by a mated mother - 0.039-0.183 (Duguma et al. 2002, Lee et al. 2009, Mroczkowski et al. 1981, Olivier et al. 1998, 2001, Piwczyński 2009). Such significant differences in presented values of heritability indices may be caused, among other things, by the method or model used in statistical analysis.

The objective of the study was to compare the effects of heritability and repeatability estimates for lambs born and reared, obtained by means of the Average Information REML and Gibbs sampling using a linear and a threshold model.

\section{Material and methods}

The research was conducted on 3844 dams of the Polish Merino breed, born in the years 1991-2001 and used in 15 flocks from Pomerania and Kujawy, Poland. Data on descent and performance of sheep came from the breeding documentation from the years 1990-2004, made available by the Local Sheep and Goat Breeders Association in Bydgoszcz. The animals which underwent reproduction performance assessments between 1993 and 2003 were at the age of 2 to 12 . The assessed parameters were the number of lambs born from a dam after lambing $(\operatorname{LSB})(1,2,3)$ and the number of lambs reared by a mated dam (LSW) $(0,1,2,3)$.

Table 1

Descriptive characteristic of number of lambs born (LSB) and reared (LSW)

\begin{tabular}{lccc}
\hline Trait & $\mathrm{n}$ & Mean & Standard deviation \\
\hline LSB & 15938 & 1.318 & 0.481 \\
LSW & 15938 & 1.250 & 0.518 \\
\hline
\end{tabular}

The pedigree information of the studied animal population was, if possible, completed up to 3rd generation. In total the pedigree database comprised 9297 animals. In order to calculate the inbreeding index in the studied population, the INBREED procedure from the SAS package (SAS 2008) was used. Twenty inbred animals were found with the mean inbreeding of $14.76 \%$ (SD=10.04\%). 
Table 2

Distribution of number of lambs born (LSB) and reared (LSW)

\begin{tabular}{lcrc}
\hline Trait & Level & $\mathrm{n}$ & $\%$ \\
\hline LSB & 1 & 10991 & 68.96 \\
& 2 & 4830 & 30.3 \\
& 3 & 117 & 0.73 \\
LSW & 0 & 554 & 3.48 \\
& 1 & 10942 & 68.65 \\
& 2 & 4351 & 27.3 \\
& 3 & 91 & 0.57 \\
\hline
\end{tabular}

As part of the statistical determination, the basic measures of location and variability of controlled traits were calculated. An explorative analysis of LSB and LSW was carried out using multiple logistic regression (SAS 2008). In the course of the analysis, using the selection method of the forward type regression model, the following variables, associated with the above traits, were selected: flock, year of birth, ewe's age and birth type, and flock $\times y e a r$ of birth interaction. The significance of parameters, i.e. the selected variables, was evaluated by means of the Wald statistics (SAS 2008). The statistical analysis was conducted with the use of the SAS computer package, applying the LOGISTIC procedure (SAS 2008).

The LSB and LSW genetic parameters were estimated by means of two methods: Average Information - Restricted Maximum Likelihood (Al-REML) and Gibbs sampling (GS). Estimating components by means of the AI-REML method the animal's linear model (LM) was applied, and in the case of the GS method, a threshold model was used alongside a linear one (TM).

The GIBBS1F90 software (Misztal 2007) was used to estimate the LSB and LSW genetic parameters according to a linear model, and the THRGIBBS1F90 (Tsuruta \& Misztal 2006) according to a threshold model.

Estimating variance components by means of the Gibbs sampling method, 100000 samples were generated, 40000 of which were considered as so-called "burn-in« samples. Due to occurrence of autocorrelation of results obtained from adjacent samples, genetic parameters were determined based on values obtained from every 100th sample. Variance components as well as heritability and repeatability indices were therefore determined based on results of 600 samples. The POSTGIBBS1F90 computer software (Tsuruta \& Misztal 2006) was used to determine the number of samples initially rejected.

Below is the linear model applied to estimate variance components.

$$
y=X_{f y} \beta_{f y}+X_{w} \beta_{w}+X_{t} \beta_{t}+Z_{a} a+Z_{p e} p e+e
$$

where $y$ is the $15938 \times 1$ observation vector, $\beta_{f y^{\prime}} \beta_{w^{\prime}} \beta_{t}$ are the fixed effects vectors: flock-year

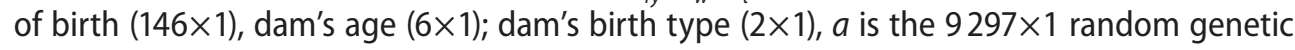
additive effects vector, $\boldsymbol{p e}$ is the $9297 \times 1$ random permanent environment effects vector, $X_{f y} X_{w} X_{t}$ are the incidence matrices for permanent effects: flock-year of birth $(15938 \times 146)$, dam's age $(15938 \times 6)$; dam's birth type $(15938 \times 2), Z_{a}$ is the $15938 \times 9297$ incidence matrix for random direct additive genetic effects, $Z_{p e}$ is the $15938 \times 9297$ incidence matrix for random permanent environment effects and $e$ is the $15938 \times 1$ random errors vector. 
The following assumptions concerning the random effects variance model were adopted:

$$
\operatorname{var}(\boldsymbol{a})=\boldsymbol{A} \sigma_{a^{\prime}}^{2}, \operatorname{var}(\boldsymbol{p e})=I_{q} \sigma_{p e}^{2}, \operatorname{var}(\boldsymbol{e})=I_{n} \sigma_{e^{\prime}}^{2}
$$

where $A$ is the $9297 \times 9297$ dimensional additive relationship matrix, $I_{n}$ and $I_{q}$ are the identity matrices, $\sigma_{a}^{2}$ is the direct additive genetic variance, $\sigma_{p e}^{2}$ is the random permanent environment effects variance, $\sigma_{e}^{2}$ is the error variance and $\sigma_{p}^{2}$ is the phenotypic variance $\left(\sigma_{p}^{2}=\sigma_{a}^{2}+\sigma_{p e}^{2}+\sigma_{e}^{2}\right)$.

While estimating variance components with the use of a threshold model, the same random and fixed effects were taken into account, the difference, however, was that with this model the modelled parameter was the so-called »unobserved tendency«.

Estimating genetic parameters with the Al-REML method, the same convergence index, equal to $10^{-10}$, was adopted for all models. Errors of estimated (co)variances were approximated according to the method described by Klei \& Tsuruta (2008). In the case of the GS method, standard variance components errors and genetic parameters, determined based thereon, were calculated as standard deviations for the values of these components, and indices obtained from the abovementioned 600 samples.

Heritability $\left(h^{2}\right)$ and repeatability $\left(r^{\prime}\right)$ were obtained applying the following formulas, respectively:

$$
h^{2}=\frac{\sigma_{a}^{2}}{\sigma_{p}^{2}} \quad r^{\prime}=\frac{\left(\sigma_{a}^{2}+\sigma_{p e}^{2}\right)}{\sigma_{p}^{2}}
$$

\section{Results}

Table 1 shows basic measures of location and variability of the number of lambs born and reared. The share of multiple litters in the studied population was approximately 30 (Table 2).

Using the multiple regression method the following independent variables were selected, which were significantly associated with the number of lambs born and reared: flock, year of birth, age, and ewe's birth type, flock $\times$ year of birth interaction. The selected variables were taken into account while estimating (co)variance components.

The values of LSB heritability indices estimated by means of the AI-REML and GS (linear model) methods were similar (Table 3). Also similar were the values of standard errors for variance components. Applying the GS method in combination with a threshold model resulted in obtaining nearly two times higher heritability compared to that obtained when using linear models. A similar tendency in terms of the influence of the model and method on obtained results was noted for estimated repeatability. Heritability of the number of lambs reared was basically similar regardless of estimation model and method, it fluctuated between 0.016 and 0.020 . Influence of the model type was noted in terms of repeatability index, i.e. a significantly higher result was obtained using a threshold model. 
Table 3

Estimates of (co)variances components, heritability and repeatability of number of born (LSB) and reared lambs (LSW)

\begin{tabular}{lcccccc}
\hline & & LSB & & & LSW & \\
& REML-LM & GS-LM & GS-TM & REML-LM & GS-LM & GS-TM \\
\hline$\sigma_{\mathrm{a}}^{2}$ & 0.0053 & 0.0061 & 0.0137 & 0.0039 & 0.0049 & 0.0032 \\
$\mathrm{SD} \sigma_{\mathrm{a}}^{2}$ & 0.0019 & 0.0021 & 0.0049 & 0.0020 & 0.0021 & 0.0018 \\
$\sigma_{\mathrm{pe}}^{2}$ & 0.0084 & 0.0078 & 0.0162 & 0.0082 & 0.0074 & 0.0081 \\
$\mathrm{SD} \sigma_{\mathrm{pe}}^{2}$ & 0.0021 & 0.0021 & 0.0053 & 0.0023 & 0.0022 & 0.0022 \\
$\sigma_{\mathrm{e}}^{2}$ & 0.1999 & 0.1998 & 0.2237 & 0.2385 & 0.2384 & 0.1498 \\
$\mathrm{SD} \sigma_{\mathrm{e}}^{2}$ & 0.0025 & 0.0025 & 0.0079 & 0.0030 & 0.0030 & 0.0029 \\
$\sigma_{\mathrm{p}}^{2}$ & 0.2136 & 0.2137 & 0.2535 & 0.2506 & 0.2507 & 0.1610 \\
$\mathrm{~h}^{2}$ & 0.025 & 0.029 & 0.054 & 0.016 & 0.019 & 0.020 \\
$\mathrm{SD} \mathrm{h} \mathrm{h}^{2}$ & & 0.010 & 0.019 & & 0.008 & 0.011 \\
$\mathrm{r}^{\prime}$ & 0.064 & 0.065 & 0.118 & 0.048 & 0.049 & 0.070 \\
$\mathrm{SD} \mathrm{r} \mathrm{r}^{\prime}$ & & 0.006 & 0.012 & & 0.006 & 0.010 \\
$\sigma_{\mathrm{e}}^{2} / \sigma_{\mathrm{p}}^{2}$ & 0.936 & 0.935 & 0.8824 & 0.952 & 0.951 & 0.930 \\
\hline
\end{tabular}

LM: linear model, TM: threshold model

\section{Discussion}

Mean numbers of lambs born and reared, presented in Table 1, are typical of the Polish Merino bred in Poland (Sheep And Goats Breeding In Poland In 2008, 2009).

The research results confirm low influence of genetic assumptions on the number of lambs born and reared. The values of heritability and repeatability indices of both the traits found in the research are basically very much the same as those found by many other authors (Altarriba et al. 1998, Bromley et al. 2000, Hanford et al. 2002, 2003, Matos et al. 1997a, Okut et al. 1999, Olivier et al. 2001, Piwczyński 2009, Sousa et al. 2000). Considerably higher values of heritability index for ewe prolificacy were found by De Vries et al. (2005), Mroczkowski et al. (1981) in German Merino and Blackhead research. His estimates were made using analysis of variance.

Bromley et al. (2000), Hanford et al. (2002, 2003), Matos et al. (1997a), Okut et al. (1999), Olivier et al. (2001), Piwczyński (2009), Sousa et al. (2000) estimated heritability of the number of lambs born and reared with the use of the REML method and a linear model obtaining value ranges as follows: LSB - 0.01-0.23, LSW - 0.00-0.17. Matos et al. (1997a) and Piwczyński (2009) also estimated repeatability of this traits, and it equalled respectively: LSB - 0.107-0.111, LSW - 0.074. On the other hand, research based on using a threshold model (Altarriba et al. 1998, Matos et al. 1997a, Piwczyński 2009) resulted in obtaining the following values of heritability indices: LSB - 0.077-0.250, LSW - 0.054. Exceptionally high values of LSB heritability index (0.34-0.43), rising in subsequent litters, and estimated with the use of a threshold model and the Gibbs sampling method, were obtained by Yazdi et al. (1999). Altarriba et al. (1998) and Piwczyński (2009) conducted research on determining LSB repeatability, and obtained values ranging as follows: LSB $-0.141-0.186$, LSW -0.102 .

Based on conducted research it was found that heritability estimated in respect of the number of lambs born was higher than that relating to the number of lambs reared, which is compatible with findings of numerous other studies (Bromley et al. 2000, Hanford et al. 2002, 
2003, Okut et al. 1999, Olivier et al. 2001, Piwczyński 2009, Sousa et al. 2000). It may suggest that selection on the number of lambs born (prolificacy) should be more efficient than on the number of lambs reared from a mated dam.

In this research it was established that higher differences between estimations made using linear and threshold models occurred in respect of the number of lambs born as compared to reared (Table 3). Probably it is a result of a smaller number of trait 3 categories $(1,2,3)$ and not $4(0,1,2,3)$. Abdel-Azim \& Berger (1999) proved that increase in the number of trait value categories improves estimation accuracy, and at the same time the difference between estimations made using linear an threshold models decreases.

Currently conducted researches, similarly to an earlier one (Piwczyński 2009), are proof that the Al-REML and GS estimation methods yields similar outcome when a linear model is applied.

A number of authors (Matos et al. 1997a, Olesen et al. 1994, Piwczyński 2009, Sousa et al. (2000) have dealt with comparisons of heritability estimates obtained by means of linear and threshold models based on the same numerical input. Results of their researches confirm results of research by authors hereof, namely higher values of estimated indices were obtained when applying a threshold model as opposed to a linear model - twice as high, for the most part. One may presume that considerably higher heritability and repeatability indices obtained using threshold models as compared to linear models likely stem from the fact that threshold models account for the majority of total variability (Matos et al. 1997a, Olesen et al. 1994, Piwczyński 2009, Sousa et al. 2000).

A decision on whether to choose a linear or threshold model in order to estimate variance components may be taken based on measures of model quality. Kadarmideen et al. (2000) established that estimates obtained with the use of a threshold model usually have a higher standard error. Also, Olesen et al. (1994) conducted a genetic analysis of the number of lambs born, using linear and threshold models. They proved that model quality measures (MSE as well as the index of correlation between actual and forecast values) and predictive ability were similar in the case of both the linear and the threshold model (sire component). AbdelAzim \& Berger (1999) and Matos et al. (1997b) on the other hand, comparing accuracy of estimates made with the use of two different models, by means of such measures as MSE and predictive ability, found that they were similar or slightly more favourable in the case of a threshold model. Taking into account error variance percentage (\%) in the total phenotypic variance, one may conclude that a threshold model accounts slightly better for total variability than a linear one.

Concluding, it must be said that estimated values for heritability of the number of lambs born in a litter point to low participation of genetic assumptions in shaping the phenotype of this trait regardless of the mathematical model used for estimation. The research showed low repeatability of the number of lambs born and reared. It was established that genetic parameters estimations made with the use of linear models as well as AI-REML and GS methods were similar. At the same time, approximately two times higher values were obtained using a threshold model. From the applied models, a threshold model was found to be the more adequate one, due to better accounting for total variability. 


\section{References}

Abdel-Azim GA, Berger PJ (1999) Properties of threshold model predictions. J Anim Sci 77, 582-590

Altarriba J, Varona L, Garcia-Cortés LA, Moreno C (1998) Bayesian inference of variance components for litter size in rasa Aragonesa sheep. J Anim Sci 76, 23-28

Bromley CM, Snowder GD, van Vleck LD (2000) Genetic parameters among weight, prolificacy and wool traits of Columbia, Polypay, Rambouillet and Targhee sheep. J Anim Sci 78, 846-858

Dempster ER, Lerner IM (1950) Heritability of threshold characters Genetics. 35, 212-236

De Vries F, Hamann H, Distl O (2005) Genetic parameter for reproduction traits in land sheep breedes. Arch Tierz 48, 76-85 [in German]

Dobek A, Wójtowski J, Szwaczkowski T, Molinski K, Gut A (2004) Genetic variability for birth and fourth week weights in sheep. Arch Tierz 47, Special Issue, 64-72

Duguma G, Schoeman SJ, Cloete SWP, Jordaan GF (2002) Genetic and environmental parameters for ewe productivity in Merinos. S Afr J Anim Sci 32, 154-159

Gianola D (1982) Theory and analysis of threshold characters. J Anim Sci 54, 1079-1096

Hagger C (2002) Multitrait and repeatability estimates of random effects on litter size in sheep. Anim Sci 74, 209-216

Hanford KJ, van Vleck, LD, Snowder GD (2002) Estimates of genetic parameters and genetic change for reproduction, weight, and wool characteristics of Columbia sheep. J Anim Sci 80, 3086-3098

Hanford KJ, van Vleck, LD, Snowder GD (2003) Estimates of genetic parameters and genetic change for reproduction, weight, and wool characteristics of Targhee sheep. J Anim Sci 81, 630-640

Kadarmideen HN, Thompson R, Simm G (2000) Linear and threshold model genetic parameters for disease, fertility and milk production in dairy cattle. Anim Sci 71, 411-419

Klei B, Tsuruta S (2008) Approximate variance for heritability estimates. http://nce.ads.uga.edu/html/projects/ Al_SE.pdf [last accessed 23.02.2011]

Lee GJ, Atkins KD, Sladek MA (2009) Genetic parameters for lifetime reproductive performance of merino ewes. Proc Assoc Advmt Anim Breed Genet 18, 382-385

Matos CAP, Thomas DL, Gianola D, Tempelman RJ, Young LD (1997a) Genetic analysis of discrete reproductive traits in sheep using linear and nonlinear models: I Estimation of genetic parameters. J Anim Sci 75, 76-87

Matos CAP, Thomas DL, Gianola D, Perez-Enciso M, Young LD (1997b) Genetic analysis of discrete reproductive traits in sheep using linear and nonlinear models: II Goodness of fit and predictive ability. J Anim Sci 75, 88-94

Misztal I (2007) BLUPF90 family of programs. http://nce.ads.uga.edu/ ignacy/newprograms.html [last accessed 28.06.2011]

Mroczkowski S, Schnarr W, Wassmuth R (1981) Heritability of fertility in Merino-sheep and black-face-meat sheep, Züchtungskunde 53, 71-77 [in German]

Naazie A, Makarechian M, Berg RT (1991) Genetic, phenotypic, and environmental parameter estimates of calving difficulty, weight, and measures of pelvic size in beef heifers. J Anim Sci 69, 4793-4800

Noor RR, Djajanegara A, Schüler L (2001) Selection to improve birth and weaning weight of Javanese Fat Tailed sheep. Arch Tierz 44, 649-659

Okut H, Bromley CM, van Vleck LD, Snowder GD (1999) Genotypic expression at different ages: I Prolificacy traits of sheep. J Anim Sci 77, 2357-2365

Olesen I, Perez-Enciso M, Gianola D, Thomas DL (1994) A comparison of normal and nonnormal mixed models for number of lambs born in Norwegian sheep. J Anim Sci 72, 1166-1173

Olivier WJ, Snyman MA, van Wyk JB, Erasmus GJ (1998) Genetic parameter estimates for fitness traits in South African Merino sheep. Livest Prod Sci 56, 71-77

Olivier WJ, Snyman MA, Olivier JJ, van Wyk JB, Erasmus GJ (2001) Direct and correlated responses to selection for total weight of lamb weaned in Merino sheep. S Afr J Anim Sci 31, 115-121 
Piwczyński D (2004) Heritability and repeatability of some reproductive traits of Polish Merino sheep. [in Polish] Zesz Nauk ATR in Bydgoszcz, Zootechnica 34, 29-33 [in Polish]

Piwczyński D (2009) Improvement of performance traits in Polish Merino. postdoctoral dissertation 135, Appl Sci Rep of University of Technology and Life Sciences in Bydgoszcz, Poland [in Polish]

Saboulard M, Russell WC, Riley M L (1995) Selection for lambing rate and clean fleece weight in sheep. J Anim Sci 73, 3195-3198

SAS (2008) SAS/STAT User's guide 9.2. SAS Institute Inc., Cary, NC, USA

Schmalwasser T, König KH, Al-ASli A (1991) Selection for fertility in Merino Mutton and Merino long wool sheep. I.: Heritability of fertility parameters and reliability of breeding values estimation for fertility. Arch Tierz 34, 69-75 [in German]

Sheep And Goats Breeding In Poland In 2008 (2009) The Polish Sheep Breeders Association, Warsaw [in Polish]

Sousa WH, Pereira CS, Bergmann JAG, da Silva FLR (2000) Estimates of components of variance and genetic parameters for reproductive traits by means of linear and threshold models. Rev Bras Zoot 29, s.2, 22372247 [in Portuguese]

Strittmatter K (2004) The fine wool Mutton Merino in Germany - currently breed condition and problems. Arch Tierz 47, Special Issue, 25-35 [in German]

Süß R, Siersleben K, Rösler H-J, Döring L. (2004) Analysis of the economic situation of sheep farms in SaxonyAnhalt. Arch Tierz 47, Special Issue, 135-141 [in German]

Szyda J (2001) Application of the covariance function approach with an iterative two-stage algorithm to the estimation of parameters of a random regression test day model for dairy production traits. J App Genet 44, 177-191

Tsuruta S, Misztal I (2006) THRGIBBS1F90 for estimation of variance components with threshold and linear models. J Dairy Sci 89, Suppl 1, 15

Vries de MJ, van der Waaij EH, van Arendonk JAM (1998) Estimation of genetic parameters for litter size in sheep: A comparison of a repeatability and multivariate model. Anim Sci 66, 685-688

Yazdi MH, Johansson K, Gates P, Näsholm A, Jorjani H, LiljedahI LE (1999) Bayesian analysis of birth weight and litter size in Baluchi sheep using gibbs sampling. J Anim Sci 77, 533-540

Received 19 January 2010, accepted 23 February 2011.

Corresponding author:

Dariusz Piwczyński

email: darekp@utp.edu.pl

University of Agriculture and Life Sciences in Bydgoszcz, Faculty of Biology and Animal Breeding, Department of Genetics and General Animal Breeding, Mazowiecka Street 28, 85-084 Bydgoszcz, Poland 